\title{
APPLICABILITY OF FEM AND PUSHOVER ANALYSIS TO SIMULATE THE SHAKING-TABLE RESPONSE OF A MASONRY BUILDING MODEL WITH TIMBER DIAPHRAGMS
}

\author{
MARIA PIA CIOCCI ${ }^{{ }^{*}}$, RUI MARQUES ${ }^{2}$ AND PAULO B. LOURENÇO ${ }^{2}$ \\ ${ }^{1}$ Institute for Sustainability and Innovation in Structural Engineering (ISISE), \\ Department of Civil Engineering, University of Minho, \\ Campus de Azurém, 4800-058 Guimarães, Portugal \\ e-mail: mariapiaciocci@gmail.com, web page: https://isise.net (*corresponding author) \\ ${ }^{2}$ Institute for Sustainability and Innovation in Structural Engineering (ISISE) and \\ Institute of Science and Innovation for Bio-Sustainability (IB-S), \\ Department of Civil Engineering, University of Minho, \\ Campus de Azurém, 4800-058 Guimarães, Portugal \\ e-mail: marquesmnc@sapo.pt, e-mail:pbl@civil.uminho.pt \\ web page: https://isise.net, web page: http://ib-s.uminho.pt/
}

Keywords: FE Modelling, Mass-proportional Pushover Analysis, Flexible Diaphragms, Unreinforced Masonry, Wall-to-diaphragm Connections

\begin{abstract}
The seismic behaviour of unreinforced masonry (URM) structures is generally governed by a complex interaction between the out-of-plane and in-plane responses of the walls, depending on the in-plane stiffness of floor/roof diaphragms and the efficiency of wallto-floor/roof connections. The presence of timber diaphragms, which are typically characterised by low in-plane stiffness and poor connection to the masonry walls, adds challenges to the numerical modelling and analysis, as well as to the structural assessment of URM structures under seismic actions. This work aims at investigating the applicability of refined FE modelling using macro-modelling approach and mass-proportional pushover analysis for simulating the response of URM structures with flexible diaphragms, comparing the results with experimental data obtained from incremental dynamic testing.

A full-scale two-storey prototype building with timber diaphragms, which was tested in shaking table at the European Centre for Training and Research in Earthquake Engineering (EUCENTRE), in Italy, was considered to perform this study. A refined finite element (FE) model was developed in DIANA software, considering the wall-to-diaphragm (WTD) connections. While the strength values of masonry were adopted according to axial and diagonal compression tests, the modulus of elasticity was calibrated after simulating in-plane cyclic shear tests of masonry piers, which were part of the same experimental program at EUCENTRE. Recommendations from international guidelines were used to derive the assumed material properties for diaphragms and wall-to-diaphragm connections. Mass-proportional pushover analysis was performed and a comparison between numerical and experimental results is presented to investigate the assumptions, advantages and limitations of the presented numerical modelling and analysis approach.
\end{abstract}




\section{INTRODUCTION}

Despite the formidable inventory of unreinforced masonry (URM) buildings with a large variety in terms of geometry, materials and construction techniques, they present some common features that make them high vulnerable to earthquakes. Such features include but are not limited to: (1) low material strength; (2) unfavourable geometrical layout; (3) high mass of the masonry structural elements when compared to diaphragms; (4) inappropriate stiffness of diaphragms; (5) poor connection between intersecting walls and between walls and diaphragms. Due to these characteristics, URM buildings frequently collapse in a quasi-brittle way with outof-plane mechanisms of isolated parts that behave independently from the rest of the structure (i.e. overturning and flexure failure mechanisms). When the premature activation of these failure modes is prevented, an integral structural behaviour can develop with an associated global mechanism of the building which allows to exploit the in-plane capacity of the walls [1].

The timber diaphragms and their connection to masonry walls may have an important role when assessing the seismic response of URM structures, because of their influence on the activation and type of out-of-plane mechanisms. For this reason, their consideration is recommended by several international building codes and guidelines [2-4]. Indeed, when adequate in-plane diaphragm stiffness and efficient wall-to-diaphragm (WTD) connections are provided, the sudden out-of-plane overturning of walls can be prevented. Still, the successful performance of diaphragms and connections does not preclude the possibility of flexural outof-plane mechanisms, which are however associated with higher performance when compared

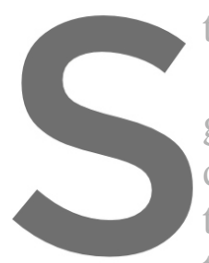
to wall overturning.

\section{In current practice,} global analyses on refin questions which arise w timber flexible diaphragms ard tools. Timber diaphragms are typically implen
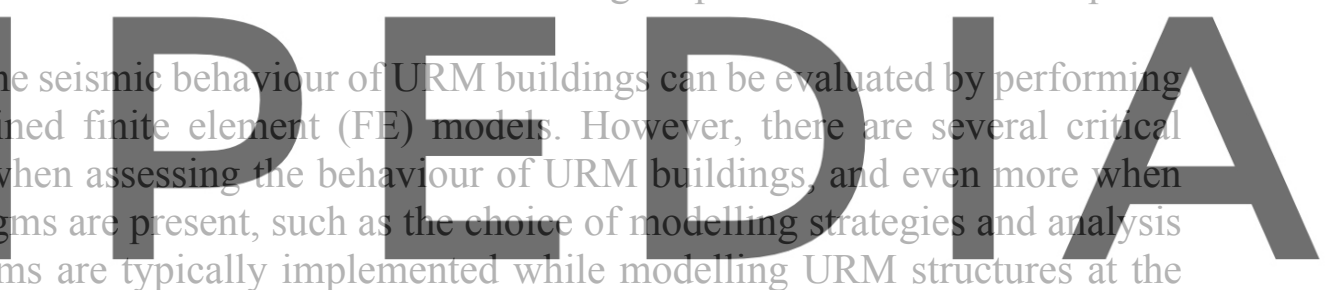

building scale by assuming a linear elastic behaviour, with input material properties calculated

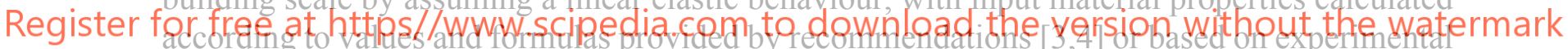

tests at the component level (e.g. [5]). This assumption is corroborated by the fact that prior to the failure of the connections between walis and floors, usualiy there is no scope for diaphragms to exploit their nonlinear behaviour. As regards WTD connections, very little information is currently available on their structural characteristics and behaviour, leading to simplified assumptions to consider their contribution when assessing the structural behaviour of URM buildings with timber floors. As regards analysis methods, nonlinear static (pushover) analysis is commonly used, especially for refined FE numerical models which are associated to a significant computational burden. However, several aspects involved when pushover analysis is performed (e.g. adequate lateral load pattern) are still open issues for URM structures, particularly in presence of flexible diaphragms.

This paper presents a numerical study aimed to simulate the behaviour of a full-scale twostorey prototype building, representative of existing double-leaf stone masonry buildings with wooden floors and roofs, which was subjected to shaking table testing at the European Centre for Training and Research in Earthquake Engineering (EUCENTRE), in Italy [6,7]. Firstly, numerical simulations of in-plane shear tests of masonry piers were perfomed to calibrate the modulus of elasticity for masonry, and then the model of the prototype building was analysed 
by means of mass-proportional pushover analysis. Hence, the modelling strategy and the analysis tool used in this study are evaluated with respect to experimental data.

\section{REFERENCE EXPERIMENTAL PROGRAM}

The experimental program carried out by [6-8] at EUCENTRE (Italy) was selected as a reference for this study. This program was aimed to investigate the seismic response of URM buildings with timber floors and roofs, and the efficiency of different strengthening interventions to improve diaphragm stiffness and WTD connections. The experimental program included an extensive characterisation of the masonry, comprising uniaxial and diagonal compression tests as well as in-plane shear tests on masonry piers, and shaking table tests on three full-scale prototype buildings. The main features of the reference unstrengthened prototype building (Building 1) and the in-plane cyclic shear tests of masonry piers, which were numerically simulated in this study, are summarised in the following sections.

\subsection{Shaking table testing}

The prototype building (Building 1) had a rectangular single-room of plan dimensions 5.8 $\mathrm{m} \mathrm{x} 4.4 \mathrm{~m}$, two-storeys and an asymmetrical distribution of openings (Figure 1). The walls were made of double-leaf stone masonry, with a thickness of $0.32 \mathrm{~m}$. As regards the timber floor and roof systems, they consisted of $3 \mathrm{~cm}$ thick single layer of planks nailed to joists which were placed every $0.5 \mathrm{~m}$ and oriented in the direction of the shortest span, and simply supported on
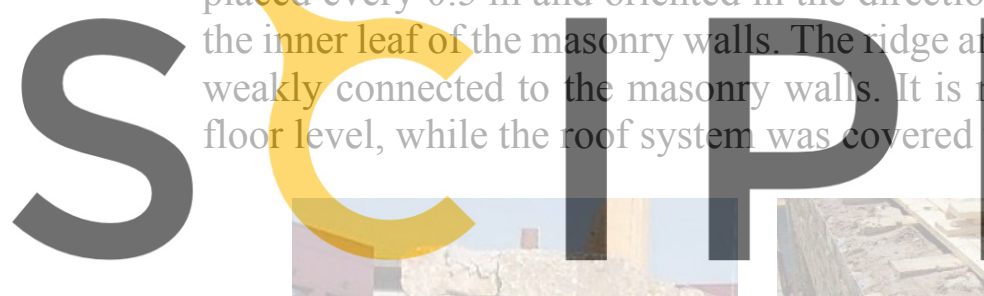

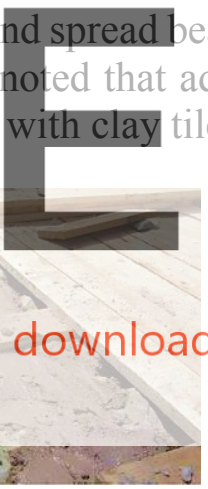

(b)

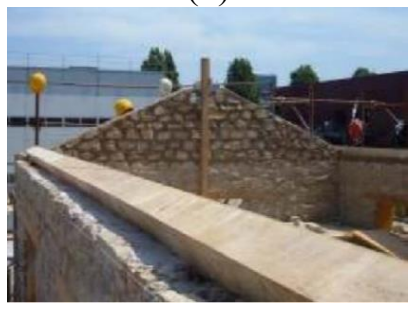

(d)

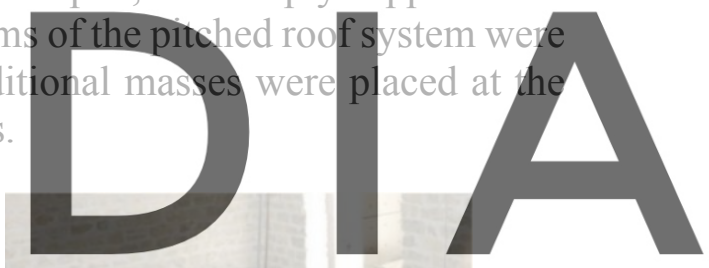

the version without the watermark

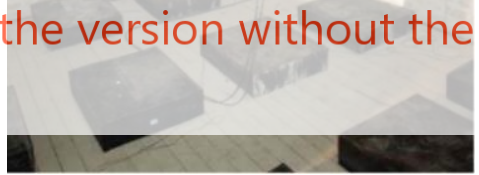

(c)

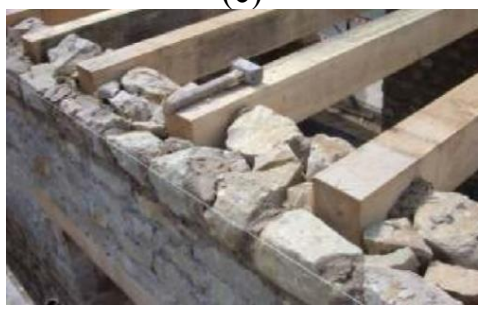

(e)

Figure 1: Prototype building (Building 1): (a) masonry wall, (b-c) timber floor, (d-e) timber roof [11]

During shaking table testing, accelerometers were installed at the mid-span and at the corners of the walls at both floor and roof levels in order to monitor the building response. The ground motion recorded during the 1979 Montenegro earthquake was applied to the building prototype in the horizontal direction parallel to the longitudinal walls. The intensity of the ground motion 
was gradually increased in each test run, scaling the reference input until a near collapse condition was reached. It should be mentioned that during the final run of the incremental dynamic testing sequence, tie-rods were applied at both diaphragms' levels in order to prevent out-of-plane collapse mechanisms [8].

\subsection{In-plane cyclic tests}

The experimental program included testing of four masonry piers which were subjected to in-plane reversed horizontal cyclic loading (Figure 2). All specimens were constructed with a nominal thickness of $0.32 \mathrm{~m}$ and were $2.5 \mathrm{~m}$ high. Two geometric configurations were tested under different levels of axial loading, namely 0.2 and $0.5 \mathrm{MPa}$. The specimens CT01 and CT02 (squat piers) had a slenderness ratio $(h / l)$ equal to 1 , while a slenderness ratio of 2 was assumed for specimens CS01 and CS02 (slender piers). While the vertical axial loading was kept constant, a cyclic horizontal displacement history was applied, both at the top of each specimen. Detailed information about the loading protocol can be found in [10]. As regards boundary conditions, the test setup imposed a double bending configuration by means of a "hybrid" control of the vertical actuators which were forced to apply a constant total axial load as well as to maintain the same vertical displacement.

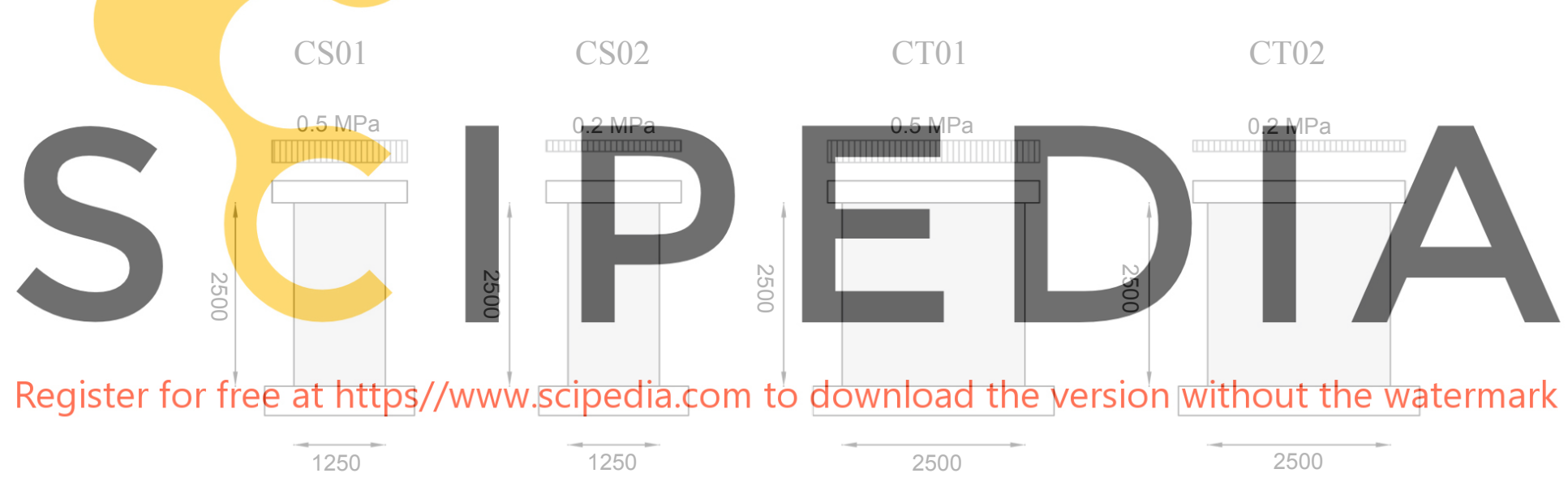

Figure 2: In-plane shear cyclic tests of masonry piers (dimensions in $\mathrm{mm}$ )

\section{REFERENCE MODEL OF THE BUILDING PROTOTYPE}

The FE model of the prototype building was developed in the finite element environment DIANA 10.3 [11]. The masonry walls were modelled with solid elements, while curved shell elements were used for the floor and timber diaphragms. As regards WTD connections at floor level, they were implemented in the model by means of beam elements embedded in the masonry walls. At the roof level, the ridge and spreader beams were modelled as beam elements resting on the walls. It should be noted that the shell elements simulating the diaphragms were connected to the in-plane masonry walls only at nodes corresponding to the location of the WTD connections (Figure 3a).

In order to simulate the mechanical behaviour of masonry, the Total Strain Rotating Crack (TSRC) model was used considering specified compressive and tensile softening behaviour (Figure $3 \mathrm{~b}$ ). The strength values necessary for this model were adopted based on the axial and 
diagonal compression tests performed within the same EUCENTRE experimental program [12]. As regards the modulus of elasticity, a value of $2550 \mathrm{MPa}$ was derived from the the axial compression tests. As discussed later in Section 4, this value was subsequently calibrated by performing model updating based on numerical simulation of in-plane shear tests of masonry piers. Fracture energy values which control the softening were not measured experimentally and had to be derived from information available in the literature. A summary of the material properties adopted for masonry is presented in Table 1.

For the shell elements, an equivalent shear modulus was adopted to simulate the timber floor and roof diaphragms. Since limited information was available for these structural components, this value was assumed to be equal to $8.8 \mathrm{MPa}$, calculated according to recommendations provided in the New Zealand guidelines for a $3 \mathrm{~cm}$ thick single straight sheathing diaphragm subjected to loading in the perpendicular direction of joists [3].

Regarding the connection elements between masonry walls and floor joists, the input material properties were evaluated according to EN 338:2016 [13]. An equivalent mass density was assigned to these elements to lump the diaphragms' masses in correspondence to the WTD connections.
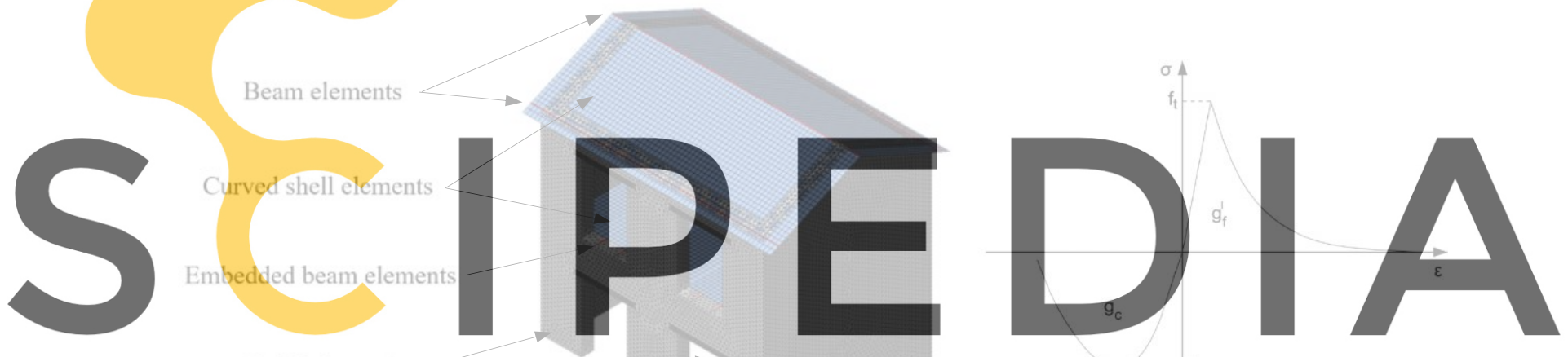

Solid elements

Register for free at https//www.scipedia.com to download the version without the watermark

(a)

(b)

Figure 3: Modelling of the prototype building: (a) FE model, (b) TSRC model

Table 1: Characterisation of masonry material

\begin{tabular}{lc}
\hline Masonry material properties & \\
\hline Modulus of elasticity (MPa) & $800^{*}$ \\
\hline Poisson ratio (-) & 0.20 \\
\hline Compressive strength $(\mathrm{MPa})$ & 3.28 \\
\hline Tensile strength $(\mathrm{MPa})$ & 0.14 \\
\hline Fracture energy in compression $(\mathrm{N} / \mathrm{mm})$ & 12.90 \\
\hline Fracture energy in tension $(\mathrm{N} / \mathrm{mm})$ & 0.012 \\
\hline Specific weight $\left(\mathrm{kN} / \mathrm{m}^{3}\right)$ & 23.0 \\
\hline * Calibrated value &
\end{tabular}




\section{NUMERICAL SIMULATION OF IN-PLANE CYCLIC TESTS}

Eigenvalue analysis performed on the model of the prototype building adopting the value of modulus of elasticity derived from the vertical compression tests, i.e. $2550 \mathrm{MPa}$, resulted in much higher natural frequencies when compared to the results obtained from dynamic identification tests performed on the specimen before the shaking table test [14]. To investigate better this discrepancy, additional numerical simulations of the in-plane cyclic shear tests presented in Subsection 2.2 were performed. Figure 4a presents the numerical model used to perform this study.

The material properties for masonry were kept with the same values presented in Table 1, except the modulus of elasticity. The vertical axial loading applied at the top of the wall included both the overburden stress load as well as the self-weight of the beam used in the test setup. Proper boundary conditions were implemented in the model to reproduce the double bending configuration assumed in the experimental test, and the loading was applied consistently with the time horizontal displacement history presented in [10]. The results obtained for specimen CT02 are presented in this paper.

Despite the unloading and reloading are simulated by a secant approach in the TSRC model, which leads to an underestimation of energy dissipation under cyclic loading condition [15], the numerical model reasonably simulated the experimental behaviour of the specimen in the scope of this study. As shown in Figure 4b, the initial stiffness was well captured by the model when the modulus of elasticity was assumed to be equal to $800 \mathrm{MPa}$, comparable with the value

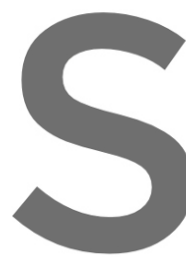
obtained from model tpr fairly predicted the expe the model exhibited dra observed experimenta. the value of modulus of building.
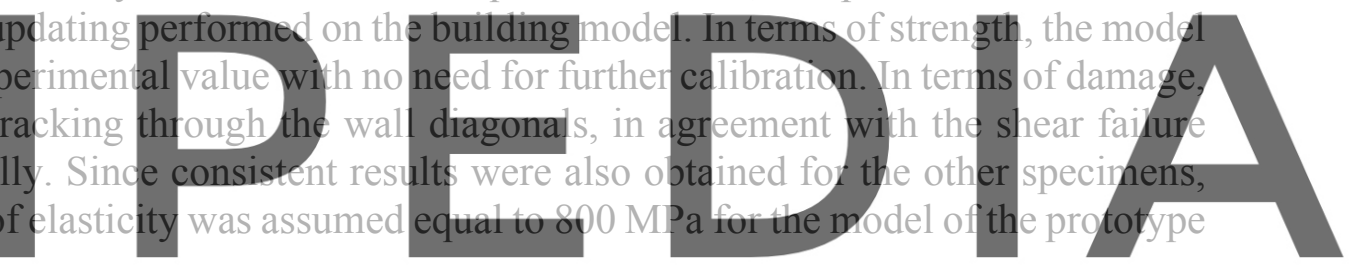

Register for free at https//www.scipedia.com to download the version without the watermark

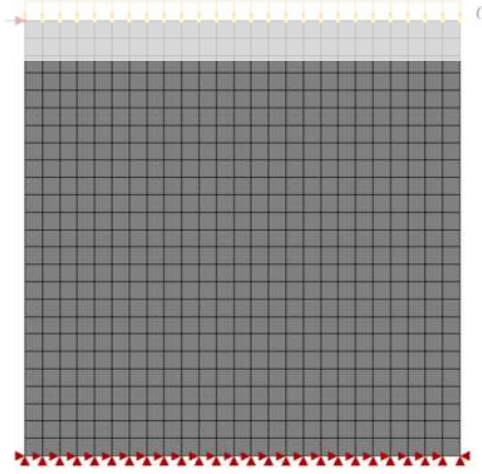

(a)

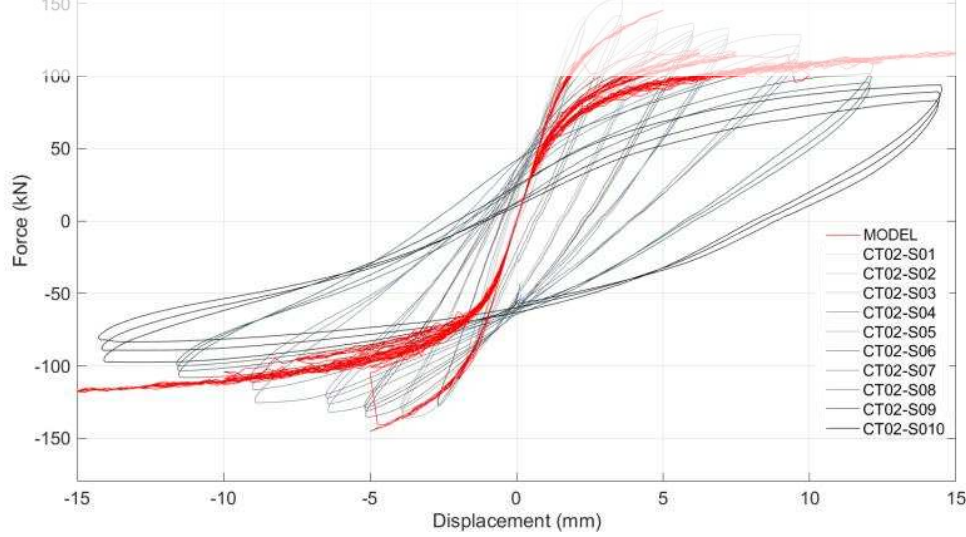

(b)

Figure 4: In-plane shear test simulation of specimen CT02: (a) FE model, (b) force-displacement hysteresis 


\section{NONLINEAR STATIC ANALYSES}

The need for nonlinear analysis when dealing with masonry structures is widely recognized. Nonlinear dynamic (time-history) analysis is able to follow the full seismic loading process, considering significant aspects of the structural response; however, it is challenging to perform due to its intrinsic complexity and large computational effort involved. For this reason, nonlinear static (pushover) analysis is usually preferred in common practice, especially for refined FE numerical models which need a significant computational burden.

The reference experimental program involved incremental dynamic testing in which the building was subjected to a series of accelerations. Experimentally the structure was inherently subjected to loading spatially distributed as per its mass [16]. Consequently among the various methods of applying the load that can be employed while performing pushover analyses, massproportional loading was chosen in this study. Hence, the reference model was analysed performing pushover analyses with loading in the positive (NS) and negative (SN) senses of the longitudinal direction, i.e. the direction of ground motion in the shaking table tests.

Figure 5 presents the comparison between experimental and numerical predictions in terms of capacity curves, i.e. the base shear force-displacement response, plotting the base shear force $\left(V_{\text {base }}\right)$ versus the horizontal displacement values recordered at nodes at the top level. Moreover, damage obtained in the numerical model is compared to damage documented in the shaking table test. In particular, Figure 6a shows in red cracks occurred in step 5 of the experimental test and in black the ones observed in previous phases.

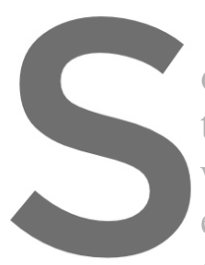

As shown in Figure 5

of the building prototyp

the curves obtained for

which was also obser

experimental response,

experimental damage, no significant cracks occurrc
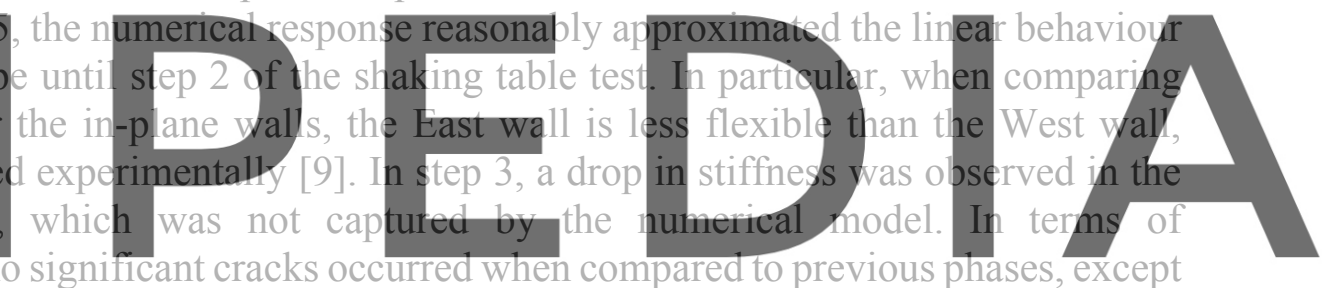

for cracks due to transportation of the building prototype [9], which were not implemented in

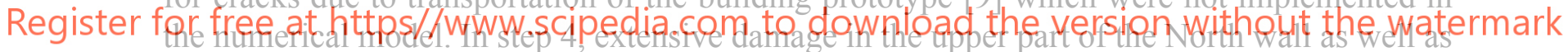

in the in-plane walls was observed. A good agreement between numerical and experimental predictions was in general obtained for damage in the in-plane walis (Figure 6). As regards the North wall, the numerical model captured the out-of-plane mechanism above the floor level, involving also portions of the in-plane walls. However, some differences were observed in terms of damage pattern. In step 5, the numerical model predicted the vertical crack which occurred in the mid-length of the South wall at the roof level, but it could not properly predict the horizontal crack observed at the base of the South gable wall. It should be noted that 'falsepositive' cracks were predicted by the numerical model when compared to experimental results. As shown in Figure 6, vertical cracking occurred at the South-East (SE) and North-East (NE) corners, which were not observed experimentally. Extensive damage was also predicted close to the wall-to-diaphragm connections at roof level, which was not reported in the experimental observations.

In terms of maximum base shear force, the numerical model presents a value which is $35 \%$ higher than the experimental one in both positive and negative senses. It should be noted that some contribution to these differences can be related with dissimilar methodologies used when constructing the capacity curves. The numerical responses were defined by considering the base 
shear force recorded at the nodes at the base of the model versus the displacement values in the longitudinal direction recorded at the location of the accelerometers in the experimental test. As regards the experimental responses, they represent the envelope of the hysteresis cycles which were evaluated during each testing phase of the building prototype. In particular, the hysteresis behaviour was defined by plotting the inertia force (sum of the product of the measured accelerations by tributary masses assumed as concentrated at each accelerometer location) versus the roof level displacements where the accelerations were recorded.
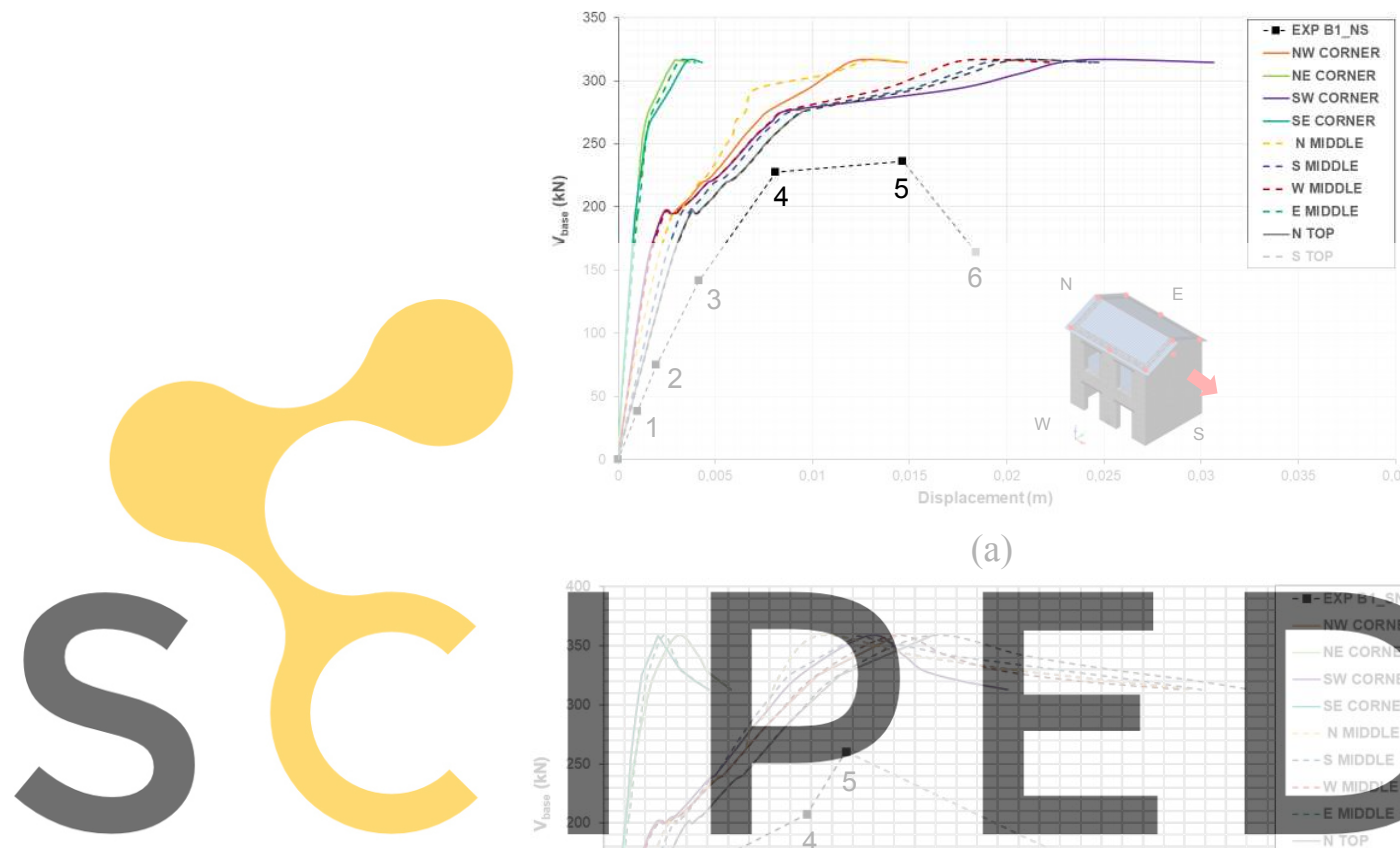

(a)

Register for free at https//www.scipedia.com to download the version without the watermark

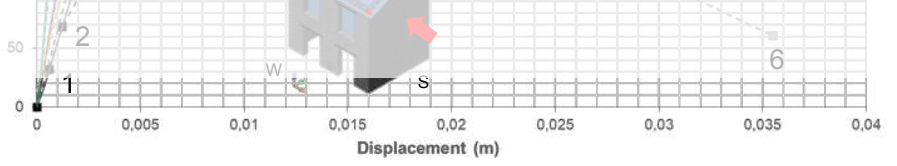

(b)

Figure 5: Capacity curves: (a) positive (NS) direction, (b) negative (SN) direction 


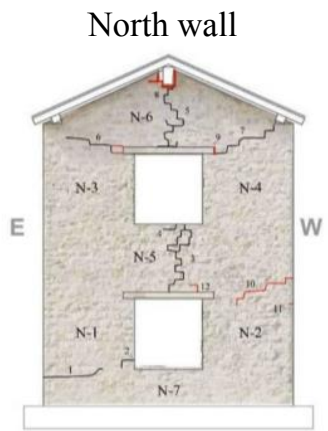

Pushover in positive (NS) direction

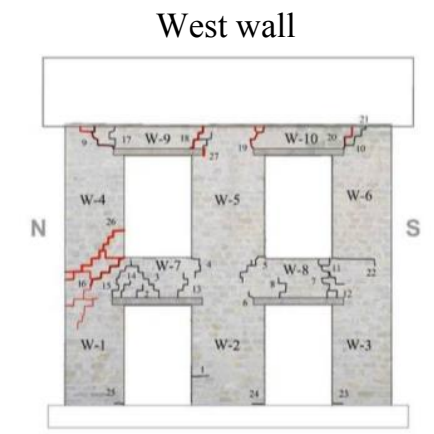

(a)

Pushover in negative (SN) direction

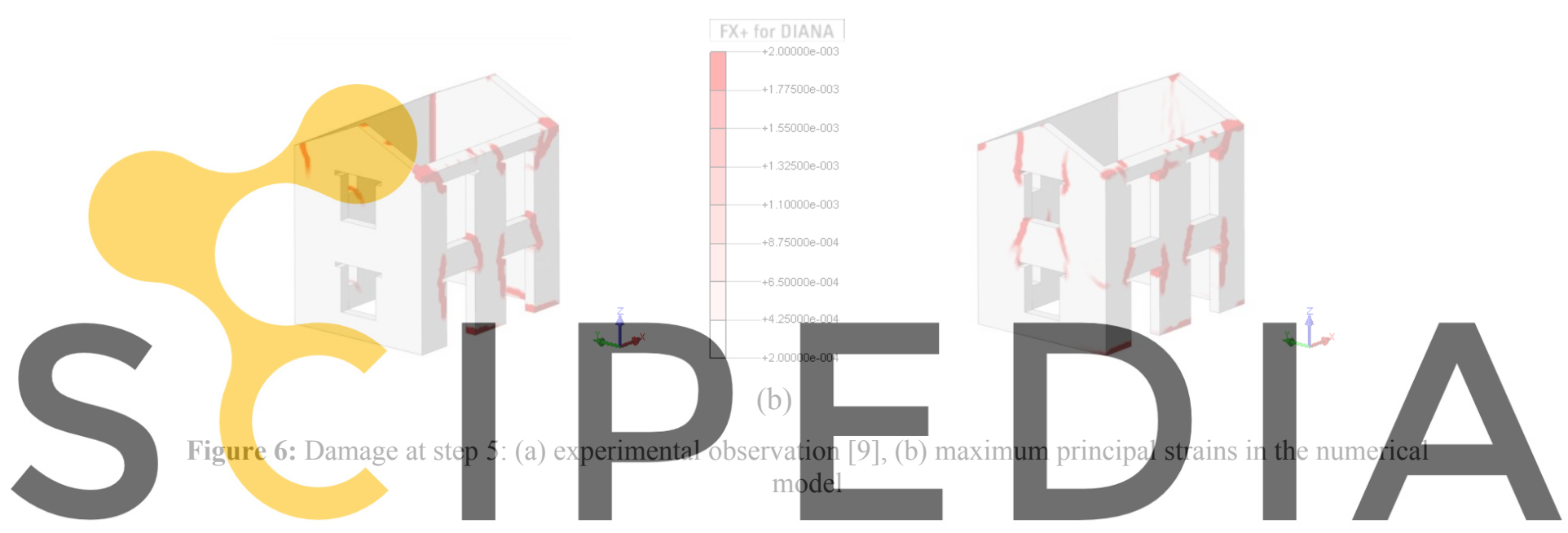

6. CONCLUSIONS

Register for free ath htths / www scipedia com to downdoad the version without the watermark

simulating the response of a URM structure with flexible diaphragms subjected to incremental

dynamic testing was investigated in this paper. The reference experimental program was carried out at EUCENTRE, in Italy, which included extensive characterization testing of the masonry and incremental shaking table testing of three full-scale two-storey prototype buildings. The unstrengthened specimen (Building 1), conceived to reproduce existing double-leaf stone masonry buildings with timber floor and roof systems, weakly connected to walls, was used to perform this work.

For the adopted modelling strategy, the masonry walls were modelled using solid elements, while curved shell elements were used for timber floor/roof diaphragms. The connection of diaphragms to the in-plane walls was modelled by means of beam elements, which were embedded in masonry at floor level. Pushover analyses were performed by applying massproportional lateral loading in the longitudinal direction of the building, consistently with the direction of the input ground motion in the incremental shaking table testing.

The results show that the numerical simulations of in-plane cyclic shear tests of masonry piers can be very useful in this work to calibrate the modulus of elasticity for masonryAs regards the numerical model of the building, the base shear force obtained numerically is approximately 
$35 \%$ higher than the experimental one. In terms of damage, the model fairly simulated the main failure mechanisms observed experimentally. However, while damage in the in-plane walls was well captured by the model, the numerical and experimental predictions were not so consistent for the out-of-plane damage. Moreover, when compared to the experimental results the model predicted 'false-positive' cracks at the connection with the transversal walls as well as at WTD connections. The results obtained from the model of the building confirm the need to enhance the contribution of in-plane stiffness of diaphragm and their connection to masonry walls in the building response, which will be pursued in further development of this work.

Acknowledgements. This work was financed by FCT - Portuguese Foundation for Science and Technology, within the INFRARISK PhD program and ISISE (Ref. UID/ECI/04029/2019). The authors would like to acknowledge Prof. Guido Magenes and Dr. Ilaria Senaldi for providing useful information on the experimental program at EUCENTRE.

\section{REFERENCES}

[1] Lourenço, P.B., Mendes, N., Ramos, L.F. and Oliveira, D.V. Analysis of masonry structures without box behavior. Int J Archit Herit (2011) 5:369-382. https://doi.org/10.1080/15583058.2010.528824.

[2] NTC 2018. Norme Tecniche per le Costruzioni. Decreto Ministeriale 17/1/2018 (2018).

[3] NZSEE 2017. The existing Assessment of Existing Buildings. Part C8: Unreinforced
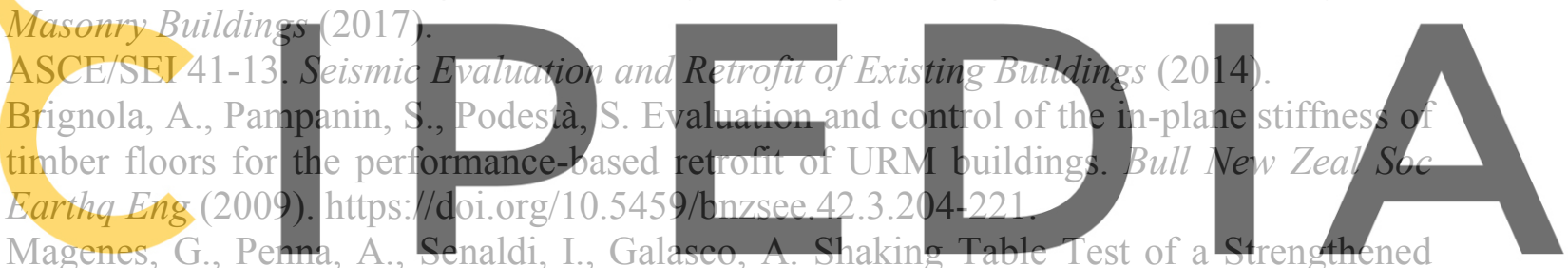

Full-Scale Stone Masonry Building with Flexible Diaphragms. Int J Archit Herit (2014)

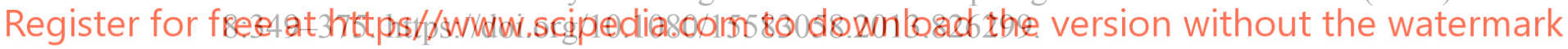

[7] Senaldi, I., Magenes, G., Penna, A., Galasco, A., Rota, M. The Effect of Stiffened Floor and Roof Diaphragms on the Experimental Seismic Response of a Full-Scale Unreinforced Stone Masonry Building. $J$ Earthq Eng (2014) 18:407-43. https://doi.org/10.1080/13632469.2013.876946.

[8] Magenes, G., Penna, A., Galasco, A. A full-scale shaking table test on a two-storey stone masonry building. In: Proceedings of the 14th European Conference Earthquake Engineering (2010).

[9] Senaldi, I. The influence of floor and roof diaphragms on the seismic response of existing masonry buildings. PhD Thesis, School of Advanced Studies IUSS Pavia, Italy (2012).

[10] Magenes, G., Penna, A., Galasco, A., Da Paré, M. In-plane cyclic shear tests of undressed double-leaf stone masonry panels. In: Proceedings of the 8th International Masonry Conference (2010).

[11]DIANA FEA BV. Diana User's Manual, Release 10.3. DIANA FEA BV 2019. https://doi.org/10.1080/15421400600788682.

[12] Magenes, G., Penna, A., Galasco, A., Rota, M. Experimental characterisation of stone masonry mechanical properties. In: Proceedings of the 8th International Masonry Conference (2010). 
[13]EN 338:2016. Structural timber - Strength classes. European Committee for Standardization, Brussels, Belgium.

[14] Kouris, L.A.S., Penna, A., Magenes, G. Dynamic Modification and Damage Propagation of a Two-Storey Full-Scale Masonry Building. Adv. Civ. Eng (2019). https://doi.org/10.1155/2019/2396452.

[15] Schreppers, G.M., Garofalo, A., Messali, F., Rots, J. DIANA Validation report for Masonry modelling (2017).

[16] Vaculik, J.. Unreinforced masonry walls subjected to out-of-plane seismic actions. $\mathrm{PhD}$ Thesis, University of Adelaide, Australia (2012). 